\title{
FINITE ELEMENT SIMULATION OF MEMS PIEZOELECTRIC ENERGY SCAVENGER BASED ON PZT THIN FILM
}

\author{
Aliza Aini Md Ralib ${ }^{1}$, Nur Wafa AsYiQin Zulfakher ${ }^{1}$, \\ ROSMINAZUIN AB RAHIM, NOR FARAHIDAH ZA'BAH \\ AND NOOR HAZRIN HANY MOHAMAD HANIF ${ }^{2}$ \\ ${ }^{I}$ Department of Electrical and Computer Engineering, \\ ${ }^{2}$ Department of Mechatronics Engineering, \\ International Islamic University Malaysia, \\ P.O. Box 10, Kuala Lumpur 50728, Malaysia. \\ *Corresponding author: alizaaini@iium.edu.my
}

(Received:27th Aug 2018; Accepted:24 th Jan 2019; Published on-line: $1^{\text {st }}$ June 2019)

https://doi.org/10.31436/iiumej.v20i1.991

\begin{abstract}
Vibration energy harvesting has been progressively developed in the advancement of technology and widely used by a lot of researchers around the world. There is a very high demand for energy scavenging around the world due to it being cheaper in price, possibly miniaturized within a system, long lasting, and environmentally friendly. The conventional battery is hazardous to the environment and has a shorter operating lifespan. Therefore, ambient vibration energy serves as an alternative that can replace the battery because it can be integrated and compatible to micro-electromechanical systems. This paper presents the design and analysis of a MEMS piezoelectric energy harvester, which is a vibration energy harvesting type. The energy harvester was formed using Lead Zicronate Titanate (PZT-5A) as the piezoelectric thin film, silicon as the substrate layer and structural steel as the electrode layer. The resonance frequency will provide the maximum output power, maximum output voltage and maximum displacement of vibration. The operating mode also plays an important role to generate larger output voltage with less displacement of cantilever. Some designs also have been studied by varying height and length of piezoelectric materials. Hence, this project will demonstrate the simulation of a MEMS piezoelectric device for a low power electronic performance. Simulation results show PZT-5A piezoelectric energy with a length of 31 $\mathrm{mm}$ and height of $0.16 \mathrm{~mm}$ generates maximum output voltage of $7.435 \mathrm{~V}$ and maximum output power of $2.30 \mathrm{~mW}$ at the resonance frequency of $40 \mathrm{~Hz}$.
\end{abstract}

ABSTRAK: Penuaian tenaga getaran telah berkembang secara pesat dalam kemajuan teknologi dan telah digunakan secara meluas oleh ramai penyelidik di seluruh dunia. Terdapat permintaan yang sangat tinggi di seluruh dunia terhadap penuaian tenaga kerana harganya yang lebih murah, bersaiz kecil dalam satu sistem, tahan lama dan mesra alam. Manakala, bateri konvensional adalah berbahaya bagi alam sekitar dan mempunyai jangka hayat yang lebih pendek. Oleh itu, getaran tenaga dari persekitaran lebih sesuai sebagai alternatif kepada bateri kerana ia mudah diintegrasikan dan serasi dengan sistem mikroelektromekanikal. Kertas kerja ini membentangkan reka bentuk dan analisis tenaga piezoelektrik MEMS iaitu salah satu jenis penuaian tenaga getaran. Penuai tenaga ini dibentuk menggunakan Lead Zicronate Titanate (PZT-5A) sebagai lapisan filem tipis piezoelektrik, silikon sebagai lapisan substrat dan keluli struktur sebagai lapisan elektrod. Frekuensi resonans akan memberikan hasil tenaga maksima, voltan tenaga maksima dan getaran jarak maksima. Mod pengendalian juga memainkan peranan penting bagi 
menghasilkan tenaga yang lebih besar. Reka bentuk yang mempunyai ketinggian dan panjang berlainan juga telah diuji dengan menggunakan bahan piezoelektrik yang sama. Oleh itu, projek ini akan menghasilkan simulasi piezoelektrik MEMS yang sesuai digunakan bagi alat elektronik berkuasa rendah. Hasil simulasi menunjukkan dengan panjang $31 \mathrm{~mm}$ dan ketinggian $0.16 \mathrm{~mm}$, piezoelektrik PZT ini menghasilkan voltan maksima sebanyak $7.435 \mathrm{~V}$ dan tenaga output maksima $2.30 \mathrm{~mW}$ pada frekuensi resonans $40 \mathrm{~Hz}$.

KEYWORDS: MEMS; piezoelectric energy harvester; PZT thin film

\section{INTRODUCTION}

Recently, researchers have shown increasing interest in wireless sensor networks (WSN). Wireless sensor networks have gained attention through many applications such as in industrial, medical, and military [1]. WSN has many advantages to the consumer because it is easier, costs less, has faster data transfer, and uses low power to save energy. However, one of the problems encountered while using WSN is that it requires a battery to supply power to sensor nodes, and that this battery presents limited capacity and limited life span. Thus, the battery will negatively affect the performance of WSN. The best solution for this problem is to get a continuous supply of energy from the environment or by harvesting energy. Energy harvesting is the term used to describe the process of converting ambient energy to electricity to power small electronic devices. Energy harvesting can contribute both environmental benefits and new technological opportunities. It produces an environmentally friendly device, it reduces the cost, and it is easy to use. Energy harvested from the surrounding environment can be used to run electronic devices directly to replace batteries for future use. There are three potential sources for energy scavenging: solar, wind, and vibration energy harvesting. For vibration energy harvesting, there are three mechanisms to generate power: piezoelectric, electrostatic, and electromagnetic [2]. Mechanical vibration energy has a greater advantage in energy harvesting through WSN while solar and wind energy may not be suitable choices because of limited access to energy sources.

The technique to harvest energy through electrostatic vibration is by converting kinetic energy to electrical energy by using a capacitor [3] while for electromagnetic vibration energy it can retrieve energy and generate voltage from the movement between a coil and a magnet [4]. Most researchers have widely used piezoelectric vibration energy scavenging because of the device's small volume. It is capable of generating electrical voltage when mechanical stress is applied. In addition, electrostatic and electromagnetic vibration energy scavenging are not the best choices because electrostatic requires a higher frequency than piezoelectric while electromagnetic has a complex design.

Piezoelectric energy harvesting is one of the effective methods for harvesting available ambient energy. Piezoelectric energy harvesting is able to transform the applied strain energy into ambient electric energy or the ability to convert the mechanical vibrations into electric energy. Piezoelectric thin films are usually fabricated in the form of a cantilever beam. One of the advantages of piezoelectric thin film is its compatibility with microelectromechanical system (MEMS) [5]. Thus, the design and simulation of piezoelectric MEMS energy harvesting is proposed in order to reduce the cost, lengthen the operating life, and provide silicon compatibility. The aim of this project is to design and simulate a MEMS piezoelectric energy harvester. The energy harvester was formed using Piezoelectric (PZT-5A) as the piezoelectric material, silicon as the substrate layer, and structural steel as the electrode layer. The rest of the paper is structured as follows. Section 2 describes the 
design concept of MEMS piezoelectric energy scavenging. The results and analysis of finite element simulation is described in Section 3. Finally, the conclusion is shown in Section 4.

\section{THEORY AND DESIGN CONCEPT}

Piezoelectric energy harvesting is able to transform the applied strain energy into ambient electric energy or the ability to convert the mechanical vibrations into electric energy [10]. Piezoelectric components are mechanically deformed in the presence of an electric field and produce an electrical charge if mechanical deformation occurs. A key aspect of piezoelectric is that it has greater power density and can easily be integrated into a system. It also can be in the form of a cantilevered beam with a couple of piezoceramic layers namely, unimorph and bimorph [6]. Figure 1 shows the cross section of a MEMS piezoelectric energy scavenger with proof mass. The design consists of a Lead Zirconate Titanate (PZT-5A), a structural steel electrode, and a silicon substrate. PZT thin film was chosen because it has very high stiffness and a large piezoelectric coefficient compared to Zinc oxide ( $\mathrm{ZnO}$ ) and Aluminum Nitride (AlN) thin piezoelectric thin films [7].

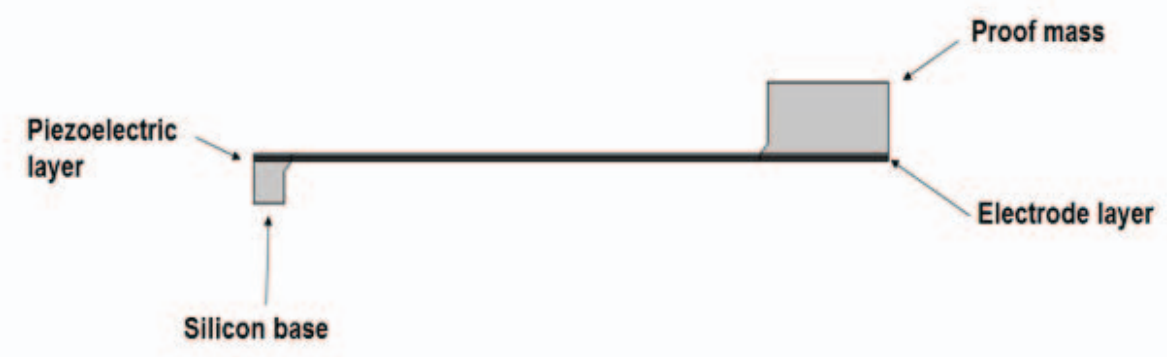

Fig. 1: Cross section of MEMS piezoelectric energy scavenger with proof mass.

Piezoelectricity is a coupling behavior of a material's mechanical and electrical properties. It is the generation of electric field from applied pressure. The symmetrically charged crystal materializes the piezoelectricity electromechanical coupling. The cathode and anode charges are distributed in a crystal symmetrically. Then, random orientation of ferroelectric domains is aligned by poling process. The poling consists of inducing DC voltage across the material. As a result of pressure being applied to the object, a negative charge is produced on the expanded side and a positive charge on the compressed side. After polarization process, the piezoelectric materials will undergo piezoelectric effects where it is divided into two different phenomenon: direct and converse piezoelectric effects. Direct piezoelectric effect means the production of electricity when stress is applied. The resonance frequency is the natural frequency of vibration that is shown in equation (1).

$$
f_{n}=\frac{1}{2 \pi} \sqrt{\frac{1}{4}} x \frac{\epsilon H^{2}}{\rho L^{4}}
$$

where:

$\mathrm{f}=$ resonance frequency of the vibration

$\epsilon=$ Young modulus of piezoelectric

$\mathrm{H}=$ thickness of the beam 
$\mathrm{L}=$ length of the beam

$\rho=$ density of the material

There has been a significant increase in research on piezoelectric materials and its properties as it has been proven to be valuable for energy scavenging applications. There are different types of piezoelectric materials for power harvesting. Some are natural piezoelectric material (e.g. silk, DNA and dentin), single crystals (e.g. $\mathrm{ZnO}$, quartz and Rochelle salt), polymers (e.g. polyvinylidene fluoride) and ceramics (e.g. sodium potassium niobate, lead zirconate titanate and barium titanate) [8-10].

Table 1: Comparison properties of piezoelectric materials

\begin{tabular}{ccc}
\hline $\begin{array}{c}\text { Piezoelectric } \\
\text { material }\end{array}$ & Form & $\begin{array}{c}d_{31} \mathbf{1 0}^{\mathbf{- 1 2}} \\
\mathrm{m} / \mathrm{v}\end{array}$ \\
\hline Quartz & Single crystal & 2.30 \\
PZT & Polycrystalline & 320 \\
PVDF & Film & 23 \\
Zinc oxide & Film & 14.3 \\
\hline
\end{tabular}

As can be seen from Table 1, PZT in polycrystalline form has the highest strain coefficient [11-12]. Table 2 illustrates the material properties of PZT-5A. Additionally, PZT also has a very broad range of dielectric constant. Thus, it can be concluded that PZT shows an excellent piezoelectric material property and has been chosen as the dominant material for piezoelectric energy harvesting.

Table 2: Material properties of PZT-5A

\begin{tabular}{ll}
\hline Parameter & Value \\
\hline Density $\left(\mathrm{kg} / \boldsymbol{m}^{3}\right)$ & 7750 \\
Elastic Constants Matrix $(\mathrm{Pa})$ & {$\left[\boldsymbol{C}_{\boldsymbol{P Z T}}\right]$ 6x6 Matrix [1] } \\
Piezoelectric Strain Coefficient, d $\left(\mathrm{C} / \boldsymbol{m}^{2}\right)$ & {$\left[\boldsymbol{d}_{\boldsymbol{P Z T}}\right] 3 \times 6$ Matrix [2] } \\
Relative dielectric constant, $\boldsymbol{\varepsilon}_{\boldsymbol{r}}$ & {$\left[\boldsymbol{\varepsilon}_{\left.\boldsymbol{r}_{\boldsymbol{P Z T}}\right] 3 \times 3 \text { Matrix [3] }}\right.$} \\
Poisson Ratio & 0.31 \\
\hline
\end{tabular}

The elastic stiffnesss coefficients, piezoelectric strain coefficient and relative dielectric constant for PZT 5A thin film are shown in equation (2)-(4)

$$
\begin{aligned}
& {\left[\begin{array}{c}
\sigma_{x x} \\
\sigma_{y y} \\
\sigma_{z z} \\
\sigma_{x y} \\
\sigma_{x z} \\
\sigma_{y z}
\end{array}\right]=\left[\begin{array}{cccccc}
1.203 \mathrm{e} 011 & 7.517 \mathrm{e} 010 & 1.203 \mathrm{e} 011 & 0 & 0 & 0 \\
x & 7.509 \mathrm{e} 010 & 7.509 \mathrm{e} 010 & 0 & 0 & 0 \\
x & x & 1.108 \mathrm{e} 011 & 0 & 0 & 0 \\
x & x & x & 2.105 \mathrm{e} 010 & 0 & 0 \\
x & x & x & x & 2.105 \mathrm{e} 010 & 0 \\
x & x & x & x & x & 0
\end{array}\right]\left[\begin{array}{l}
\varepsilon_{x x} \\
\varepsilon_{y y} \\
\varepsilon_{z z} \\
\varepsilon_{x y} \\
\varepsilon_{x z} \\
\varepsilon_{y z}
\end{array}\right] \mathrm{Pa}} \\
& d=\left[\begin{array}{cccccc}
0 & 0 & 0 & 0 & 12.294 & 0 \\
0 & 0 & 0 & 12.294 & 0 & 0 \\
-5.351 & -5.351 & 15.783 & 0 & 0 & 0
\end{array}\right]\left(\mathrm{C} / m^{2}\right)
\end{aligned}
$$




$$
\varepsilon_{r}=\left[\begin{array}{ccc}
919.1 & 0 & 0 \\
0 & 919.1 & 0 \\
0 & 0 & 826.6
\end{array}\right]
$$

\section{FINITE ELEMENT SIMULATION}

The behavior of a piezoelectric MEMS energy harvester is described using finite element simulation. The objective of the simulation is to investigate the optimum dimension of the design on the output voltage and output power produced. The structure of the boundary condition is fixed at the base. The electric field in the dielectric is computed in this interface. A force is applied at the end of the proof mass. Boundary load is used to apply pressure to boundaries. In meshing, the domain can be divided into triangular or quadrilateral subdivisions. A free triangular node has been used in this design to create a uniform triangular mesh in 2D domain. The element size is set to normal. Then, the simulation is run using COMSOL Multiphysics to determine the resonance frequency, output voltage and output power. The resonance frequency theory can be calculated using equation (1).

Table 3 and Fig. 2 show the proposed design dimensions. The length and height of the piezoelectric are varied to analyze the effect of output voltage and power to the dimensions of the piezoelectric energy harvester. It should be noted that the chosen dimensions can be fitted into low power electronics devices for the purposes of WSN.

Table 3: Proposed design dimensions

\begin{tabular}{cccc}
\hline Design & Material & $\begin{array}{c}\text { Length } \\
(\mathbf{m m})\end{array}$ & $\begin{array}{c}\text { Height } \\
\mathbf{( m m})\end{array}$ \\
\hline Substrate & $\mathrm{Si}$ & 1 & 1 \\
Piezoelectric & $\mathrm{PZT}$ & $11,16,21,26,31,36,41$ & $0.06,0.11$, \\
& & & $0.16,0.21$, \\
& & & $0.26,0.31$, \\
$0.36,0.41$ \\
Electrode & Steel & 20 & 0.04 \\
\hline
\end{tabular}

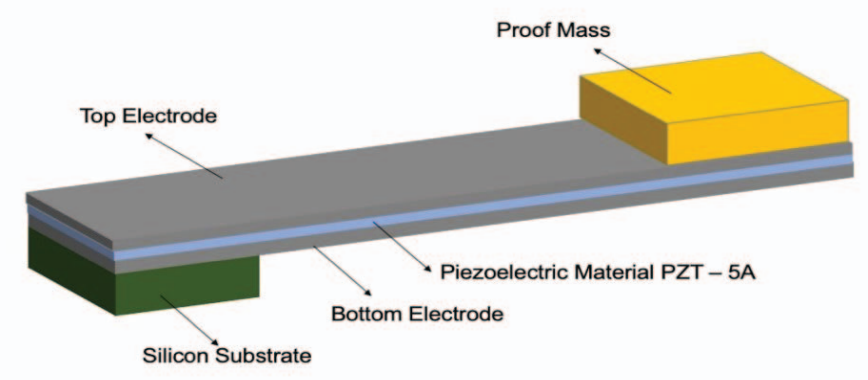

Fig. 2: 3D view of proposed design of MEMS piezoelectric energy scavenger with proof mass.

\section{RESULTS AND DISCUSSION}

Simulation results of the piezoelectric energy harvester have been analysed in determining the resonance frequency, output voltage, and output power. The objective of 
this paper is to design a MEMS piezoelectric energy harvester that is able to produce optimum power at a low frequency vibration. This design is simulated and optimized using COMSOL software. Frequency domain is a study to compute the response of a linear model when subjected into harmonic excitation for one or more frequencies. It solves the resonance frequency and the mode shape. The value of the resonance frequency, displacement and mode of the cantilever will be explained in the next section. The displacement mode of the cantilever beam is in 2D mode shape as shown in Fig. 3.

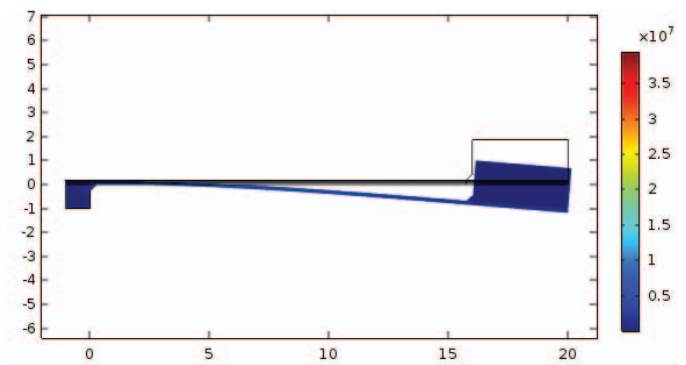

(a)

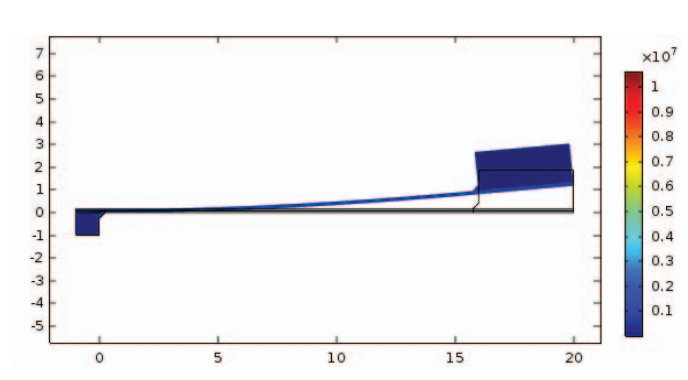

(b)

Fig. 3: Displacement of the piezoelectric energy harvester for $21 \mathrm{~mm} \times 0.16 \mathrm{~mm}$ design at (a) $79 \mathrm{~Hz}$ (b) $81 \mathrm{~Hz}$.

From the simulation results, the design produced an output power of $2.30 \mathrm{~mW}$ and output voltage of $7.435 \mathrm{~V}$ as displayed in Fig. 4. The simulation result shows the displacement of the cantilever with a value of $6.0 \times 10^{6} \mathrm{~mm}$ and resonance frequency of 80 $\mathrm{Hz}$.

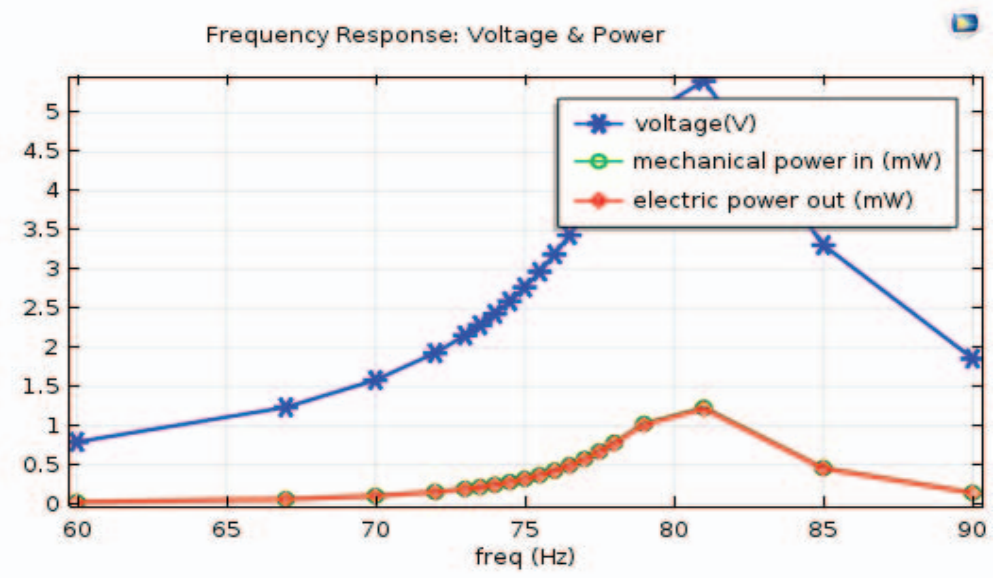

Fig. 4: Output voltage and output power of piezoelectric energy harvester versus frequency for $21 \mathrm{~mm}$ x $0.16 \mathrm{~mm}$ design at $81 \mathrm{~Hz}$ resonance frequency.

\subsection{Analysis of the Effect of Different PZT Length on Resonance Frequency, Output Voltage, and Output Power}

For this analysis, the height of the piezoelectric is fixed while the length of piezoelectric is varied to different dimensions. Variation of piezoelectric length will give a big impact on resonance frequency as shown in theory calculation. In this investigation, the length is varied in the range of $5 \mathrm{~mm}$ from $11 \mathrm{~mm}$ to $41 \mathrm{~mm}$ as depicted in Table 4. From the simulation results, it can be seen that as the length of piezoelectric increases, the resonance frequency decreases, which agrees well with equation (1). 
Table 4: Cantilever performance for different PZT length

\begin{tabular}{cccccc}
\hline $\begin{array}{c}\text { Height } \\
(\mathbf{m m})\end{array}$ & $\begin{array}{c}\text { Length } \\
(\mathbf{m m})\end{array}$ & $\begin{array}{c}\text { Resonance } \\
\text { Frequency } \\
\text { (theory) }\end{array}$ & $\begin{array}{c}\text { Resonance } \\
\text { Frequency } \\
\text { (simulation) }\end{array}$ & $\begin{array}{c}\text { Output } \\
\text { Voltage }\end{array}$ & $\begin{array}{c}\text { Output } \\
\text { power }\end{array}$ \\
\hline 0.16 & 11 & 280.30 & 260 & 2.625 & 0.287 \\
0.16 & 16 & 132.50 & 130 & 3.481 & 0.505 \\
0.16 & 21 & 77 & 81 & 5.400 & 1.220 \\
0.16 & 26 & 50.20 & 60 & 3.053 & 0.388 \\
0.16 & 31 & 35.30 & 40 & 7.435 & 2.300 \\
0.16 & 36 & 26.17 & 30 & 5.728 & 1.367 \\
0.16 & 41 & 20.20 & 30 & 2.444 & 0.248 \\
\hline
\end{tabular}

Figure 5(a) shows the frequency response for voltage. As the length of the piezoelectric increases, the resonance frequency shifts towards left side of the graph where it illustrates that the resonance frequency decreases. This is due to the fact that when the length of the PZT increases, the stiffness decreases. Thus, the resonance frequency shifts to a lower value. Varying the length can also affect the output voltage and output power. Output power versus resonance frequency is plotted in Fig. 5(b) for different lengths of PZT to show that varying the length can also affect the output power. The maximum power is obtained at the length of $31 \mathrm{~mm}$ with an output power of $2.3 \mathrm{~mW}$.

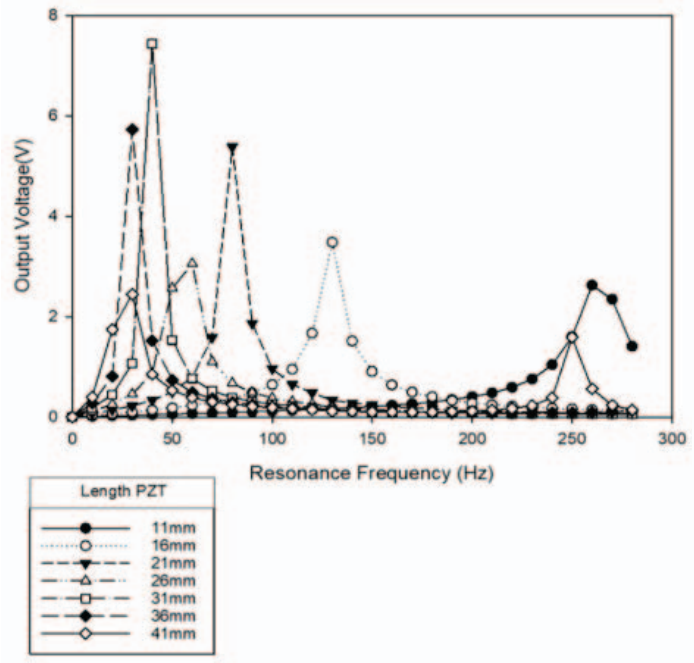

(a)

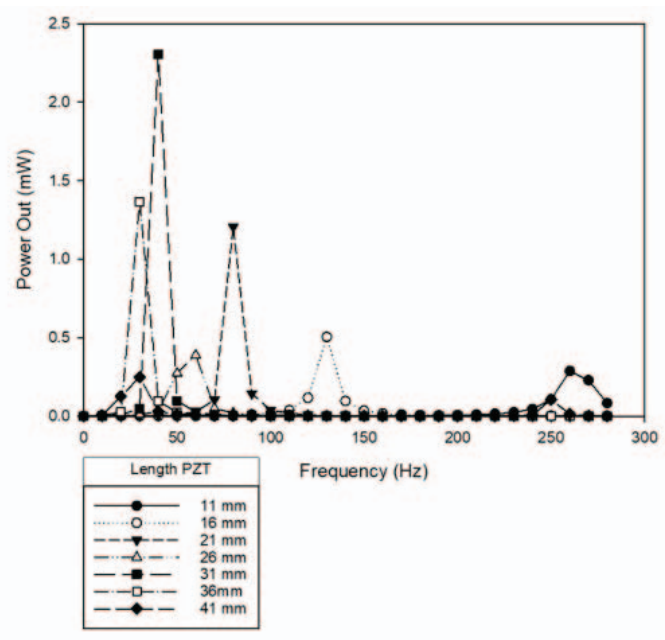

(b)

Fig. 5: (a) Resonance frequency vs output voltage, and (b) Resonance frequency vs output power for different PZT length.

In summary, the optimum length of the piezoelectric that is suitable to harvest energy is 31 $\mathrm{mm}$ because it produces a high voltage of $7.435 \mathrm{~V}$ and high output power of $2.3 \mathrm{~mW}$ with moderate resonance frequency value of $40 \mathrm{~Hz}$. 


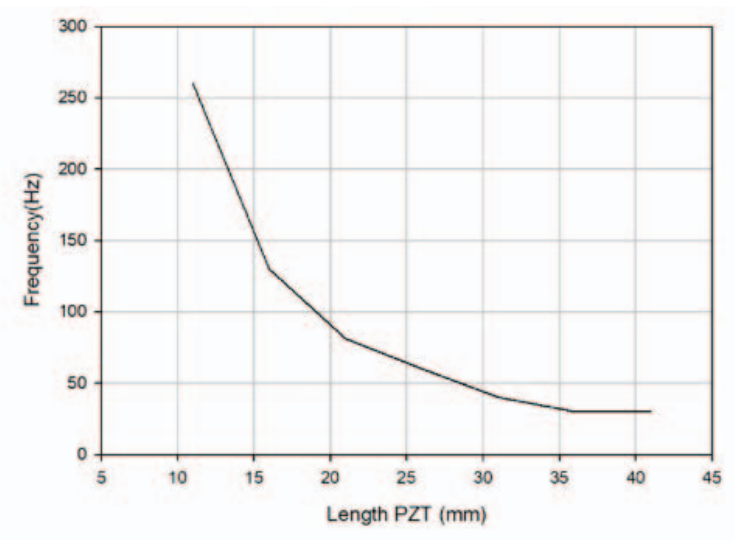

Fig. 6: PZT length vs resonance frequency at different PZT length.

\subsection{Analysis on Effect of Different PZT Height on Resonance Frequency, Output Voltage, and Output Power}

A simulation on different heights of piezoelectric has been conducted to investigate the effect of the height of the piezoelectric towards resonance frequency. The length of the piezoelectric is maintained with the optimum value of $31 \mathrm{~mm}$. The height is varied from $0.06 \mathrm{~mm}$ to $0.41 \mathrm{~mm}$. Table 5 below provides the simulation data on height of piezoelectric, resonance frequency, output voltage, and maximum power.

Table 5: Cantilever performance for different PZT heights

\begin{tabular}{cccccc}
\hline $\begin{array}{c}\text { Height } \\
(\mathbf{m m})\end{array}$ & $\begin{array}{c}\text { Length } \\
(\mathbf{m m})\end{array}$ & $\begin{array}{c}\text { Resonance } \\
\text { Frequency } \\
\text { (theory) }\end{array}$ & $\begin{array}{c}\text { Resonance } \\
\text { Frequency } \\
\text { (simulation) }\end{array}$ & $\begin{array}{c}\text { Output } \\
\text { Voltage }\end{array}$ & $\begin{array}{c}\text { Output } \\
\text { power }\end{array}$ \\
\hline 0.06 & 31 & 13.24 & 10 & 4.46 & 0.83 \\
0.11 & 31 & 24.27 & 20 & 2.33 & 0.226 \\
0.16 & 31 & 35.30 & 40 & 7.435 & 2.30 \\
0.21 & 31 & 46.33 & 60 & 6.59 & 1.80 \\
0.31 & 31 & 57.35 & 80 & 3.32 & 0.46 \\
0.36 & 31 & 68.38 & 100 & 3.80 & 0.60 \\
0.41 & 31 & 79.41 & 120 & 4.60 & 0.88 \\
\hline
\end{tabular}

Based on the results shown above, the variation of the height of the cantilever produces a higher resonance frequency. The resonance frequency increases from $10 \mathrm{~Hz}$ to $140 \mathrm{~Hz}$. The simulation results were plotted as seen in Fig. 7.

It can be seen that the graph shifted towards the right side, which indicates that the resonance frequency is increased. These results are in good agreement with the theory calculation based on equation (1). Varying the height not only affects the frequency but also affects the output voltage. As shown in the graph, the generated peak-to-peak voltage is obtained when the height of the piezoelectric is at $0.16 \mathrm{~mm}$ with resonance frequency of 40 $\mathrm{Hz}$. As displayed in Figure 7, the maximum output power can be obtained by varying the height of the PZT. From the graph, the maximum power obtained is $2.30 \mathrm{~mW}$ and optimum at the height of $0.16 \mathrm{~mm}$ with resonance frequency of $40 \mathrm{~Hz}$. Both simulation and theoretical results verified the fact that as the height of the piezoelectric increased, the resonance frequency also increased. Therefore, the height of the PZT is at optimum when the output voltage which is $7.435 \mathrm{~V}$ and output power is at $2.30 \mathrm{~mW}$ with resonance frequency of 40 $\mathrm{Hz}$. The optimum dimension value obtained based on simulation results is shown in Table 
6. PZT has shown the best performance over $\mathrm{ZnO}$ because it can generate maximum output voltage and high output power even at low frequency.

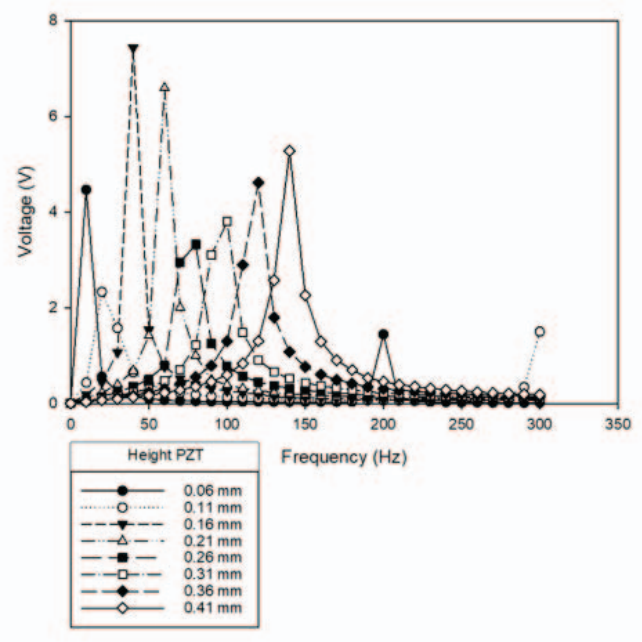

(a)

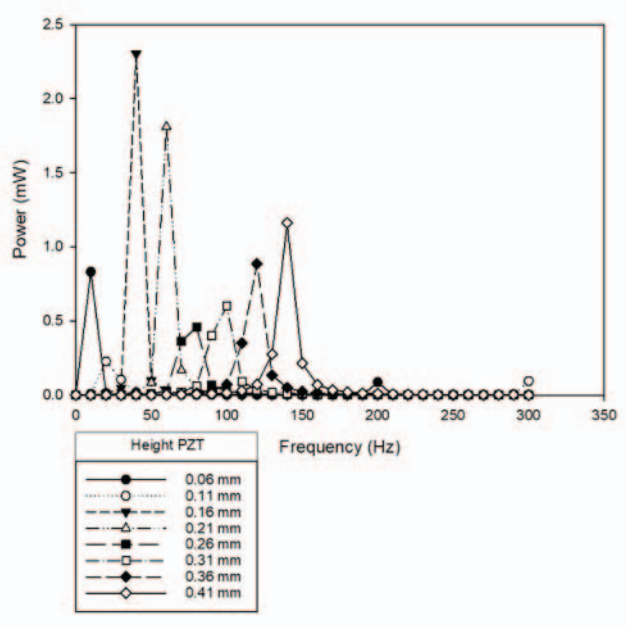

(b)

Fig. 7: (a) Resonance frequency vs output voltage, and (b) Resonance frequency vs output power for different PZT height.

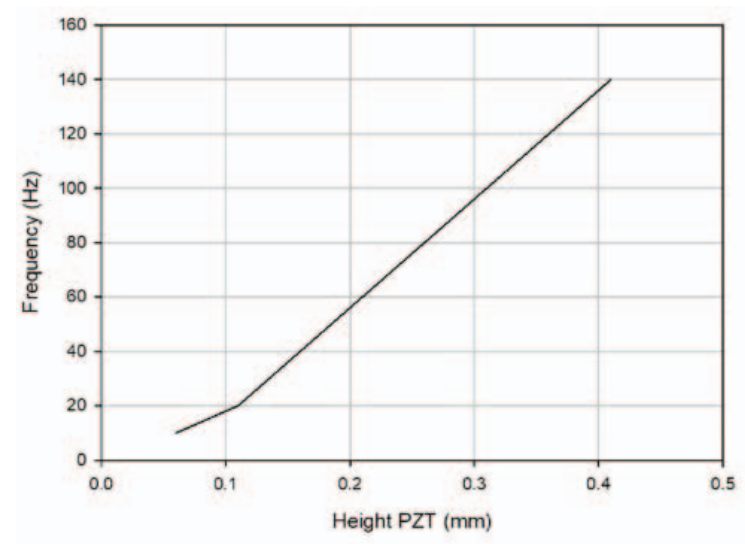

Fig. 8: PZT length vs resonance frequency for different PZT height.

Table 6: Optimum dimension of piezoelectric energy harvester

\begin{tabular}{ccccccc}
\hline $\begin{array}{c}\text { Piezoelectric } \\
\text { material }\end{array}$ & $\begin{array}{c}\text { Height } \\
(\mathbf{m m})\end{array}$ & $\begin{array}{c}\text { Length } \\
(\mathbf{m m})\end{array}$ & $\begin{array}{c}\text { Resonance } \\
\text { Frequency } \\
\text { (simulation) }\end{array}$ & $\begin{array}{c}\text { Resonance } \\
\text { Frequency } \\
\text { (theory) }\end{array}$ & $\begin{array}{c}\text { Output } \\
\text { Voltage }\end{array}$ & $\begin{array}{c}\text { Output } \\
\text { power }\end{array}$ \\
\hline PZT & 0.16 & 31 & 40 & 35.30 & 7.435 & 2.30 \\
\hline
\end{tabular}

\section{CONCLUSION}

This paper presented the finite element simulation of a MEMS Piezoelectric Energy Scavenger based on PZT thin film. The energy harvester was formed using Lead Zicronate Titanate (PZT-5A) as the piezoelectric thin film, silicon as the substrate layer, and structural steel as the electrode layer. The expected results have been obtained and analysed. The design consists of PZT-5A, a structural steel electrode, and a silicon substrate where it is simulated to gain a low frequency that can nevertheless generate a high peak-to-peak voltage and high maximum power. An analysis on the effect of the height of the piezoelectric on the 
resonance frequency has been carried out in this research. Based on the results provided above, it shows that the variation of the height of the cantilever will produce a higher resonance frequency (which increased from $10 \mathrm{~Hz}$ to $140 \mathrm{~Hz}$ ). The optimum height of the piezoelectric, that can have a big impact on the output voltage, is $0.16 \mathrm{~mm}$. Therefore, when the height of the PZT is optimal, the output voltage is $7.435 \mathrm{~V}$, output power is $2.30 \mathrm{~mW}$, and the resonance frequency is $40 \mathrm{~Hz}$. Hence, this work indicates that a MEMS Piezoelectric Energy Scavenger based on PZT thin film has high potential for the future of wireless communication system.

\section{ACKNOWLEDGEMENT}

This research was also supported by Research Initiative Grant Scheme RIGS16-083-0247 from International Islamic University Malaysia and Ministry of Higher Education Malaysia.

\section{REFERENCES}

[1] Zieliński M, Mieyeville F, Navarro D, Bareille O. (2014). A low power wireless sensor node with vibration sensing and energy harvesting capability. In IEEE Computer Science and Information Systems (FedCSIS), Federated Conference: 7-10 September 2014; Warsaw; pp. 1065-1071.

[2] Wei C, Jing X. (2017). A comprehensive review on vibration energy harvesting: Modelling and realization. Renewable and Sustainable Energy Reviews, 74: 1-18. https://doi.org/10.1016/j.rser.2017.01.073

[3] Khan FU, Qadir MU. (2016). State-of-the-art in vibration-based electrostatic energy harvesting. Journal of Micromechanics and Microengineering, 26(10): 103001. https://doi.org/10.1088/0960-1317/26/10/103001

[4] Li P, Gao S, Cai H. (2015). Modeling and analysis of hybrid piezoelectric and electromagnetic energy harvesting from random vibrations. Microsystem Technologies, 21(2): 401-414. https://doi.org/10.1007/s00542-013-2030-6

[5] Siddique ARM, Mahmud S, Van Heyst B. (2015). A comprehensive review on vibration based micro power generators using electromagnetic and piezoelectric transducer mechanisms. Energy Conversion and Management, 106: 728-747. https://doi.org/10.1016/j.enconman.2015.09.071

[6] Priya, S., Song, H. C., Zhou, Y., Varghese, R., Chopra, A., Kim, S. G., ... \& Polcawich, R. G. (2017). A review on piezoelectric energy harvesting: materials, methods, and circuits. Energy Harvesting and Systems, 4(1), 3-39.

[7] Shung KK, Cannata JM, Zhou QF. (2007). Piezoelectric materials for high frequency medical imaging applications: A review. Journal of Electroceramics, 19(1): 141-147. https://doi.org/10.1007/s10832-007-9044-3

[8] Anton SR, Sodano HA. (2007). A review of power harvesting using piezoelectric materials. Smart materials and Structures, 16(3): R1. https://doi.org/10.1088/0964-1726/16/3/R01

[9] Ralib, A. A. M., Nordin, A. N., \& Salleh, H. (2010). A comparative study on MEMS piezoelectric microgenerators. Microsystem technologies, 16(10), 1673-1681. https://doi.org/10.1007/s00542-010-1086-9

[10] Ramadan KS, Sameoto D, Evoy S. (2014). A review of piezoelectric polymers as functional materials for electromechanical transducers. Smart Materials and Structures, 23(3): 033001.

[11] Kim HU, Lee WH, Dias HR, Priya S. (2009). Piezoelectric microgenerators-current status and challenges. IEEE transactions on ultrasonics, ferroelectrics, and frequency control, 56(8),1555-1568. https://doi.org/10.1109/TUFFC.2009.1220

[12] Kim HS, Kim JH, Kim J. (2011). A review of piezoelectric energy harvesting based on vibration. International journal of precision engineering and manufacturing, 12(6): 11291141. https://doi.org/10.1007/s12541-011-0151-3 